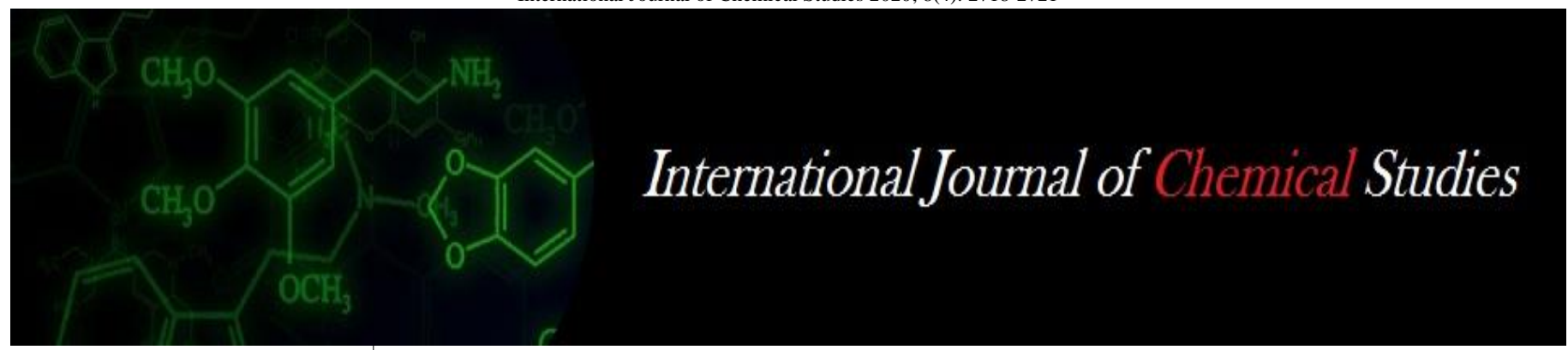

P-ISSN: 2349-8528

E-ISSN: 2321-4902

www.chemijournal.com

IJCS 2020; 8(4): 2718-2721

(C) 2020 IJCS

Received: 16-05-2020

Accepted: 20-06-2020

Deepak Kumar Yadav

Research Scholar, Department of

Agronomy, I.Ag.Sc. BHU

Varanasi, Uttar Pradesh, India

Sunil Kumar Verma

Assistant Professor, Department

of Agronomy, I.Ag.Sc. BHU

Varanasi, Uttar Pradesh, India

Vijay Pratap

Research Scholar, Division of Agronomy, ICAR-IARI, New

Delhi, India, Uttar Pradesh,

India

Shiv Poojan Yadav

Research Scholar, Department of Agronomy, I.Ag.Sc. BHU

Varanasi, Uttar Pradesh, India

Peeyush Kumar Jaysawal

Research Scholar, Department of Agronomy, BAU Ranchi,

Jharkhand, India
Corresponding Author:

Vijay Pratap

Research Scholar, Division of Agronomy, ICAR-IARI, New Delhi, India, Uttar Pradesh, India

\section{Available nutrients in soil are influenced by planting techniques and weed management options in wheat}

\author{
Deepak Kumar Yadav, Sunil Kumar Verma, Vijay Pratap, Shiv Poojan \\ Yadav and Peeyush Kumar Jaysawal
}

DOI: https://doi.org/10.22271/chemi.2020.v8.i4af.10057

\begin{abstract}
There are continue disturbance of soil under conventional wheat system as repetitive tillage practices for crop establishment results negative impact like; more weed emergence, depletion of soil nutrients and economical losses; laborious and hazardous to environment by affecting sustainability of system and creating pollution. Zero tillage practices are avoiding soil disturbance for seedbed preparation; enhance the sustainability by conserving the resources. Residue retention or application as mulching act as soil condition modifier, reducing the weed population by soil covering and after decomposition release of organic acid in soil help increase the availability of nutrient. Such practices are kept in field experiment to evaluate the zero tillage wheat with variable rate of residue application as mulch in zero tillage and weed management practices. Result revealed that zero-till wheat with 6 ton ha ${ }^{-1}$ rice residue as mulch application having higher available $\mathrm{N}, \mathrm{P}, \mathrm{K}, \mathrm{OC}, \mathrm{SMBC}$ with slightly lower $\mathrm{pH}$ and EC; while weed management practices shown Sulfosulfuron + metsulfuron @ 25+2 g a.i. ha ${ }^{-1}$ higher availability of N, P, $\mathrm{K}, \mathrm{OC}, \mathrm{SMBC}$ with slightly lower $\mathrm{pH}$ and $\mathrm{EC}$ in experimental trial.
\end{abstract}

Keywords: Available nutrients, Crop establishment methods, OC and weed management practices

\section{Introduction}

In India, wheat accounts 36 per cent of country's total food grain production from an area of 30.72 million hectare during 2016-17 as per the data estimated by Directorate of Economics and Statistics (DES), Ministry of Agriculture and Farmers Welfare (MoA\&FW), India. With an average national productivity of $3172 \mathrm{~kg} \mathrm{ha}^{-1}$ there was a record production of 98.38 million ton wheat during 2016-17. It was 4.56 percent increment in yield and marginal in the crop acreage of 0.98 per cent from the previous year. The major practices in traditional way of wheat sowing as repetitive tillage for seedbed preparation and later on broadcasting of seed and basal application of fertilizer. As the increasing of cost of production due higher prices of fuels, labour scarcity etc. and with alarming situation of natural resources, there are avoiding the disturbance of soil by repetitive practices of tillage. A huge rice residue production in ricewheat cropping system is also a major problem for making field free for sowing of crop. There is very short time period available for residue management as late harvesting of rice crop due to monsoon, duration of crop, labour shortage and viable options of immediately residue utilization. At last farmer burn the rice residue in the field which create pollution, hazardous to soil microbes and losses of nutrients. In zero tillage system there is no need of repetitive tillage of field for seedbed preparation and it can also perform the crop sowing practices in residue retention field by single opening of sleet. In single passes it can perform fertilizer placing with seed sowing and covering of seed. Rice residue application as mulch benefits as covering of help to reducing the weed emergence and addition of soil nutrients after decomposition and conserving the soil moisture. Apart from the above advantages the adoption of zero tillage sowing proved helpful in improving soil physical and chemical properties (Chaudhary et al., 2015) ${ }^{[4]}$.

Weeds are no doubt, major biotic constraints to increasing wheat production. Weed control, particularly during the initial stages of crop establishment is very essential in realizing higher yield. Oad et al. $2007^{[12]}$ reported that there are about $24-39.95$ per cent economic yield losses 
of crop due to weed while Patro and Ray (2016) ${ }^{[13]}$ reported that uncontrolled weed growth throughout the crop growing period may cause a yield reduction of 29.12 to 62.14 percent. Further, use of single herbicide may not provide an effective control due to wide diversity of weed flora observed in the field. For better yield needed multiple weed control and nutrient management options. Effective weed control often requires a combination of cultural, mechanical and chemical control measures, such as an integrated weed management approach to delay herbicide resistance and reduce the herbicide load on the agro-ecosystem. Malik et al. (2013) ${ }^{[10]}$ and Meena et al., $2016^{[11]}$ reported the tank mix application of clodinafop + metsulfuron, mesosulfuron-methyl + iodosulfuron-methyl-sodium and clodinafop + metsulfuron with and without surfactant provided excellent control of Phalaris minor, Avenafatua, Chenopodium album, Melilotus spp., Medicago denticulata, Vicia sativa, Rumex spp., Anagallis arvensis, Coronopus didymus, Lathyrus aphaca, Polygonum plebejum, sedges and many other weeds with higher grain yield of wheat.

\section{Materials and Methods}

An experimental trial was performed into the split plot design with three replication at Agricultural Research Farm, Institute of Agricultural Sciences, Banaras Hindu University, Varanasi, situated at $25^{0} 15^{\prime} 26.9^{\prime \prime} \mathrm{N}$ Latitude, 82059'17.1" E longitude and at an altitude of 74.4 meters above the mean sea level (MSL) during Rabi season of 2016-17 and 2017-18. The experimental site had homogeneously fertile with uniform textural make-up and slightly sloppy topography. Soil of the experimental field was sandy clay loam in texture with moderate fertility had low organic carbon $(0.461 \& 0.473 \%)$ and low available nitrogen (196.75 \& $\left.198.8 \mathrm{~kg} \mathrm{ha}^{-1}\right)$, and medium available phosphorus (15.63 \& $\left.16.02 \mathrm{~kg} \mathrm{ha}^{-1}\right)$ and low in potassium $\left(221.32 \& 223.7 .22 \mathrm{~kg} \mathrm{ha}^{-1}\right)$. Apart from the above, soil also indicated slightly alkaline behaviour $(\mathrm{pH} 7.5$ $\&$ 7.3). A field experiment with three crop establishment methods viz., zero tillage wheat $(Z T W)$ with 6 ton ha ${ }^{-1}$ rice reside, zero tillage wheat $(Z T W)$ with 3 ton ha $^{-1}$ rice residue and conventional tillage wheat $(C T W)$ without mulching of rice residue are performed in main plot. Weed management practices are kept into sub plot with five weed management practices viz., control (no any weed management practices), weed free (hand weeding at 20 and 40), Sulfosulfuron+ mesosulfuron $-25+2 \mathrm{~g}$ a.i. ha ${ }^{-1}$, Mesosulfuron + iodosulfuron - 12+2.4 g a.i. ha ${ }^{-1}$, Clodinafop + metsulfuron @ 60+4 g a.i. $\mathrm{ha}^{-1}$. Mulching of rice residue at $10 \mathrm{DAS}$ after emergence of crop seedling and herbicide application in field was done at 35 DAS with hand operated knapsack sprayer having flat fan nozzle. experimental field was prepared as per treatments specification and sowing of the crop using seed rate @ $125 \mathrm{~kg}$ $\mathrm{ha}^{-1}$ was done with the help of zero-till seed drill and manually line sowing after 2 harrowing and planking of field in conventional treatment at the row-to-row spacing of $22 \mathrm{~cm}$ on December 2 and November 29 in 2016-17 and 2017-18, respectively. Wheat variety HUW-234 known for its promising performance under irrigated conditions of Varanasi region of the Eastern Uttar Pradesh was used. A uniform dose of $120 \mathrm{~kg} \mathrm{~N}, 60 \mathrm{~kg} \mathrm{P}_{2} \mathrm{O}_{5}$ and $50 \mathrm{~kg} \mathrm{~K}_{2} \mathrm{O} \mathrm{ha}^{-1}$ was applied in all the treatments through urea $(46 \% \mathrm{~N})$, DAP $\left(46 \% \mathrm{P}_{2} \mathrm{O}_{5}\right)$ and muriate of potash $\left(60 \% \mathrm{~K}_{2} \mathrm{O}\right)$, respectively. Half amount of nitrogen and a full dose of phosphorus and potash were applied as basal at the time of sowing, However, remaining half dose of $\mathrm{N}$ in the form of urea was top dressed in two equal split such as after first irrigation and remaining nitrogen was a top dress at spike initiation stage. The need-based irrigations were also given to fulfil the water requirement of crop and to keep the crop in vigorous condition during both the years of investigation. At maturity, the crop was harvested manually with the help of sickle on April, 8 and 2 in 2016-17 and 2017-18, respectively. The soil samples (0-15 cm depth) from each plot with the help of augur were collected after harvest of the crop during both the years and analyzed using standard procedures. The statistical analysis of data was done using analysis of variance as described by (Gomez and Gomez, 1984) ${ }^{[6]}$ and the comparisons were made at 5 per cent level of significance.

\section{Results and Discussion pH and EC}

There are none of the crop establishment methods significantly influencing the $\mathrm{pH}$ and $\mathrm{EC}$ but $Z T W$ with rice residue mulching are shown slightly lowering the $\mathrm{pH}$ over the $C T W$ without mulching. The reason behind the lowering of $\mathrm{pH}$ in $Z T W$ with mulching is no soil disturbance, decomposition of residue resulting as organic acid released; which accumulates on surface leads to leaching of basic cations to deeper depth. Such findings are supported by Carr et al., $2013^{[3]}$. In case of EC, CTW without residue having higher compared to $Z T W$ with mulching. In conventional tillage opening of soil repeatedly and aeration in top layer of soil allowed more leaching from top layers. Such findings are supported by Kumar et al. $2018^{[8,9]}$; while at same time in $Z T W$ having larger pore size and porosity facilitate to leaching of basic cations and finally reduces EC. This is supported to the finding of Kaushik et al., 2018. In weed management practices there are higher $\mathrm{pH}$ and lower EC in weed free followed by Sulfosulfuron + mesosulfuron $-25+2 \mathrm{~g}$ a.i. ha ${ }^{-1}$, Mesosulfuron + iodosulfuron $-12+2.4 \mathrm{~g}$ a.i. $\mathrm{ha}^{-1}$ and Clodinafop + metsulfuron @ 60+4 g a.i. ha ${ }^{-1}$; respectively but the differences are non-significant.

\section{Available N (kg ha-1)}

There are none of the crop establishment methods significantly influencing the availability of nitrogen but in $Z T W$ with 6 ton ha ${ }^{-1}$ mulching are shown higher availability of nitrogen followed by ZTW with 3 ton $\mathrm{ha}^{-1}$ and $C T W$ without mulching; respectively. The reason may be large quantity of organic matter are added as mulching by rice residue, modifier of temperature and less soil disturbance in ZT. Such finding is also reported by Kaushik et al., 2018. While in $C T W$ having higher temperature due to uncovered soil, disruption of soil aggregates with exposition of protected organic matter to mineralization, faster residue decomposition and nitrogen liberationare the basic causes, to which greater nitrogen mineralization rates. Our results confirm the research findings of Issaka et al., 2019 [7]. In weed management practices there are higher available of nitrogen in weed free followed by Sulfosulfuron + mesosulfuron @ $25+2 \mathrm{~g}$ a.i. ha ${ }^{1}$, Mesosulfuron + iodosulfuron $-12+2.4 \mathrm{~g}$ a.i. ha ${ }^{-1}$ and Clodinafop + metsulfuron @ 60+4 g a.i. ha ${ }^{-1}$; respectively. In weedy check there was minimum availability of nitrogen compare to other practices but none of the weed management practices found significantly. Higher $\mathrm{N}$ availability in the herbicidal treatment may be due to effectively reducing the weed population and also reducing the competitions for applied nutrients. This is supported to the finding of Raj and Syriac, $2018^{[14]}$. 
Available P $\left(\mathrm{kg} \mathrm{ha}^{-1}\right)$

Neither crop establishment methods nor weed management practices are influenced significantly the available $\mathrm{P}$ in the soil. In crop establishment practices $Z T W$ having mulching of rice residue at different rate are showing higher availability of phosphorus compare to $C T W$ without residue application. There as on behind it may be accumulation of organic acid after decomposition of mulches; which solubilised phosphorus and increased its availability. Results are in line with the research finding of Kaushik et al., 2018. Among the weed management practices minimum availability of phosphorus found in weedy plot and highest in weed free plot. In herbicide application the phosphorus availability higher in Sulfosulfuron + mesosulfuron @ 25+2 g a.i. ha ${ }^{-1}$ followed by Mesosulfuron + iodosulfuron @ 12+2.4 g a.i. ha ${ }^{-1}$ and Clodinafop + metsulfuron @ 60+4 g a.i. ha ${ }^{-1}$; respectively. In weed free and herbicidal practices having lower weed population due to effectively management compare to the weedy check which make more availability of phosphorus. Such findings are also reported by Tomar and Tomar, 2014 ${ }^{[15]}$; Raj and Syriac, $2018^{[14]}$.

\section{Available K (kg ha-1)}

Crop establishments and weed management practices are not creating significant differences on availability of potassium but application of 6 ton $\mathrm{ha}^{-1}$ residue mulch in $Z T W$ having higher potassium availability followed by 3 ton ha-1 residue mulching in $Z T W$ and $C T W$ with no residue application. In $Z T W$ availability of higher $\mathrm{K}$ probably due to the reduction of tillage along with residue mulching. Results are in line with the research finding of Kumar and Verma, 2018. Among the herbicide practices having higher available potassium in Sulfosulfuron + mesosulfuron $-25+2 \mathrm{~g}$ a.i. ha $\mathrm{h}^{-1}$ followed by

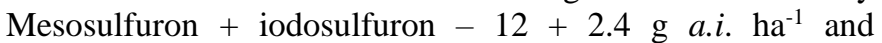
Clodinafop + metsulfuron @ 60+4 g a.i. ha ${ }^{-1}$; respectively.
This might be due to better weed control efficiency of herbicide application compare to no practices in weedy check. Supporting findings are also reported by Tomar and Tomar, $2014^{[15]}$; Raj and Syriac, $2018^{[14]}$.

\section{Organic carbon $(\%)$}

Neither crop establishment methods nor weed management practices significantly influenced the OC in the soil. Among crop establishment methods, $Z T W$ with mulching recorded higher OC due to residue application of the rice crop and minimum soil disturbance. Less OC inthe $C T W$ might be due to tilling of soil increases organic matter decomposition and decreases carbon content by increasing organic matter oxidation. In case of $Z T W$ crop roots remain intact in the root zone due to no disturbance of soil, which might facilitate enhancement of organic carbon input through their decay and also decomposition of mulching. Dixit et al., $2019^{[5]}$ are supporting such finding. With respect to weed management treatments, higher OC was recorded in Sulfosulfuron + mesosulfuron $-25+2 \mathrm{~g}$ a.i. $\mathrm{ha}^{-1}$ due to minimum weed density and dry weight compare to other treatment except weed free. The reason for higher organic carbon might be due effectively reduction in weed population.

Soil microbial biomass carbon (SMBC) ( $\mathrm{mg} \mathrm{kg}^{-1}$ of soil) Crop establishment methods and weed management practices are significantly $(\mathrm{P}=0.05)$ influenced the $\mathrm{SMBC}$ in the soil. Among crop establishment methods, $Z T W$ rice residue recorded higher SMBC probably due to higher microbial and enzymatic activities, less disturbance of soil, better aeration and more organic matter content. Such findings are also supported by Dixit et al., $2019^{\text {[5] }}$. In case of weed practices Sulfosulfuron + mesosulfuron $-25+2 \mathrm{~g}$ a.i. ha $^{-1}$ having higher SMBC probably due to less weed dry weight and higher weed control than the other herbicidal application.

Table 1: Effect of crop establishment methods and weed management of wheat on $\mathrm{pH}, \mathrm{EC}$, available N, $\mathrm{P}, \mathrm{K}, \mathrm{OC}$ and $\mathrm{SMBC}$ in soil after harvesting (mean data of two years)

\begin{tabular}{|c|c|c|c|c|c|c|c|}
\hline Treatments & \begin{tabular}{|l|} 
Nitrogen \\
$\left(\mathrm{kg} \mathrm{ha}^{-1}\right)$
\end{tabular} & $\begin{array}{c}\text { Phosphorus } \\
\left(\mathrm{kg} \mathrm{ha}^{-1}\right)\end{array}$ & $\begin{array}{c}\text { Potassium } \\
\left(\mathrm{kg} \mathrm{ha}^{-1}\right)\end{array}$ & \begin{tabular}{|l|} 
OC \\
$(\%)$
\end{tabular} & $\begin{array}{c}\text { SMBC } \\
\left(\mathrm{mg} \mathrm{kg}^{-1} \text { of soil) }\right.\end{array}$ & pH & $\mathrm{EC}\left(\mathbf{d s m}^{-1}\right)$ \\
\hline \multicolumn{8}{|l|}{ Crop establishment method } \\
\hline Zero tillage-with $100 \%$ residue $\left(6\right.$ ton $\left.\mathrm{h}^{-1}\right)$ & 199.11 & 17.74 & 226.45 & 0.477 & 195.33 & 7.49 & 0.259 \\
\hline Zero tillage -with $50 \%$ residue $\left(3\right.$ ton $\left.\mathrm{h}^{-1}\right)$ & 197.35 & 17.08 & 225.96 & 0.474 & 192.98 & 7.50 & 0.264 \\
\hline Conventional tillage-no residue & 195.06 & 16.77 & 223.91 & 0.466 & 190.47 & 7.52 & 0.266 \\
\hline SEm \pm & 1.44 & 0.29 & 0.85 & 0.009 & 0.91 & 0.07 & 0.002 \\
\hline $\mathrm{CD}(\mathrm{P}=0.05)$ & 5.65 & 1.14 & 3.33 & 0.037 & 3.56 & 0.28 & 0.009 \\
\hline \multicolumn{8}{|l|}{ Weed management practices } \\
\hline Sulfosulfuron + mesosulfuron @ 25+2 g a.i. ha ${ }^{-1}$ & 198.08 & 17.34 & 226.09 & 0.475 & 194.51 & 7.52 & 0.265 \\
\hline Mesosulfuron + iodosulfuron@ 12+2.4 g a.i. ha ${ }^{-1}$ & 196.91 & 17.32 & 225.38 & 0.473 & 192.93 & 7.49 & 0.265 \\
\hline Clodinafop + metsulfuron @ 60+4 g a.i. ha ${ }^{-1}$ & 196.26 & 16.99 & 225.08 & 0.469 & 191.89 & 7.48 & 0.259 \\
\hline Weed free & 199.05 & 17.41 & 226.53 & 0.477 & 194.86 & 7.55 & 0.267 \\
\hline Weedy check & 195.57 & 16.92 & 224.12 & 0.467 & 190.44 & 7.46 & 0.258 \\
\hline SEm \pm & 1.65 & 0.30 & 1.25 & 0.006 & 1.91 & 0.07 & 0.003 \\
\hline $\mathrm{CD}(\mathrm{P}=0.05)$ & 4.82 & 0.88 & 3.63 & 0.018 & 5.59 & 0.22 & 0.009 \\
\hline
\end{tabular}

\section{Conclusion}

Based on the results, it is suggested in the conclusion that zero-till wheat with 6 ton $\mathrm{ha}^{-1}$ rice residue application as mulching and among herbicidal practices Sulfosulfuron + mesosulfuron $-25+2 \mathrm{~g}$ a.i. ha ${ }^{-1}$ having higher available of $\mathrm{N}$, $\mathrm{P}, \mathrm{K}, \mathrm{OC}$ and SMBC.

\section{References:}

1. Adhikari KR, Dahal KR, Chen ZS, Tan YC, Lai JS. Rice-wheat cropping system: tillage, mulch, and nitrogen effects on soil carbon sequestration and crop productivity. Paddy and water environment. 2015; 15(4):699-710.

2. Annual Report ICAR - Indian Institute of Wheat and Barley Research, Karnal-132001, Haryana, India, 201718.

3. Carr PM, Gramig GG, Liebig MA. Impacts of organic zero tillage systems on crops, weeds, and soil quality. Sustainability. 2013; 5(7):3172-3201.

4. Chaudhary VP, Gangwar B, Gangwar S. Effect of longterm conservation tillage on soil physical properties and soil health under rice-wheat cropping system in sub 
tropical India. Agric. Mech. Asia, Africa, and Latin America. 2015; 46(2):61-73.

5. Dixit AK, Agrawal RK, Das SK, Sahay CS, Choudhary M, Rai AK et al. Soil properties, crop productivity and energetics under different tillage practices in fodder sorghum+ cowpea-wheat cropping system. Archives of Agronomy and Soil Science. 2019; 65(4):492-506.

6. Gomez KA, Gomez AA. Statistical procedures for agricultural research. $2^{\text {nd }}$ edition. A Wiley Inter science Publication, New York, 1984, 657.

7. Issaka F, Zhang Z, Zhao ZQ, Asenso E, Li JH, Li YT, Wang JJ. Sustainable conservation tillage improves soil nutrients and reduces nitrogen and phosphorous losses in maize farmland in Southern China. Sustainability. 2019; 11(8):2397.

8. Kumar J, De N, Pradhan A, Sharma P, Charry GR. Effect of tillage on nutrient dynamics and physical condition of soil under rainfed rice - chickpea based cropping system of Bastar, Chhattisgarh. Int. J Curr. Microbiol. App. Sci. 2018; 7(12):2843-2850.

9. Kumar S, Verma SK. Influence of crop establishment methods and zinc fertilization on soil parameters under direct-seeded rice. International Journal of Chemical Studies. 2018; 7(1):68-70.

10. Malik RS, Yadav A, Kumari R. Ready-mix formulation of Clodinafop - propargyl + metsulfuron-methyl against complex weed flora in wheat, Indian Journal of Weed Science. 2013; 45(3):179-182.

11. Meena OP, Nepalia V, Singh D, Verma A, Choudhary R. Herbicide combinations for broad spectrum weed control in wheat, Indian Journal of Weed Science. 2016; 48(3):325-327.

12. Oad FC, Siddiqui MH, Buriro U. Growth and yield losses in wheat due to different weed densities. Asian Journal of Plant Sciences. 2007; 6:173-176.

13. Patro H, Ray M. Integration of chemical and cultural methods for weed management in wheat, Advance Research Journal of Crop Improvement. 2016; 7(2):207210.

14. Raj SK, Syriac EK. Nutrient availability and nutrient uptake as influenced by the post emergence application of herbicide mixtures. Journal of Tropical Agriculture. 2018; 55(2):152-160.

15. Tomar SK, Tomar TS. Effect of herbicides and their tank mixture on weed dynamics and yield of zero-tilled wheat under rice-wheat cropping system of eastern Uttar Pradesh, Indian Journal of Agronomy. 2014; 59(4):624628. 